\title{
The Effect of Halal Certificate towards Chicken Meat Import between Brazil and Indonesia according to Rule of GATT - WTO
}

\author{
Hamzah $^{1}$, Devika Tryza Ayodahya ${ }^{2}$, MD. Shariful Haque ${ }^{3}$ \\ Fakultas Hukum Universitas Lampung ${ }^{1,2}$, Internasional Islamic University, Chittagong, \\ Bangladesh ${ }^{3}$ \\ agizaddien@gmail.com ${ }^{I}$ \\ devikatryza24@gmail.com² \\ sharif.debiiuc@gmail.com³
}

\begin{abstract}
Trade activity is one of the drivers of development in a country in order to obtain national development. In the current era of globalization, trade activities opened among the countries have developed quite rapidly. Indonesia has acquired a spinning wheel in international trade activities. Indonesia is actively involved in several negotiations concerning international trade and actively supports the national development. By becoming a member of the World Trade Organization, Indonesia has carried out important export activities to all parts of the world. Indonesia itself has special rules regarding important goods, specifically about food ingredients. Indonesia stops importing chicken because of the absence of halal labeling on these food ingredients. Indonesia is a country which most of its citizens are Muslim. Food which is consumed for Indonesia Muslim people is not only about safe and healthy but also about halal. Due to this rule, Brazil suffered a quite big loss and filled a lawsuit to WTO. The purpose of this study was to analyze the Indonesian national law regarding halal certification and how to resolve the dispute between Brazil and Indonesia on the issue of importing chicken meat.
\end{abstract}

Keywords: Consumer Protection, Halal Certificate, WTO.

\section{A. INTRODUCTION}

The importance of research on halal certification for Muslims in the current era of globalization is an urgent thing to do. At least what must be considered is the legal aspects of the trade / sale and legal relations between one country and another, including Indonesia as a country that has the largest Muslim population in the world. In protecting its citizens who are Muslims (Muslims) Indonesia has its own legal rules that cover the subject of trade in Indonesia. The main commercial law in Indonesia is the "Commercial Law" originating from the Dutch East Indies government namely Wetboek van Koophandel $(\mathrm{WvK})$, which in Indonesian is

Received : December I4, 2019 - Revised: December I4, 2019 - Accepted : December 29, 2019 Fakultas Hukum Universitas Lampung ${ }^{\mathrm{I}, 2}$, Internasional Islamic University, Chittagong, Bangladesh ${ }^{3}$

E-mail:.agizaddien@gmail.com',devikatryza24@gmail.com²,sharif.debiiuc@gmail.com² 
The Effect of Halal Certificate towards Chicken Meat Import between Brazil and Indonesia according to Rule of GATT - WTO

Hamzah $^{1}$, Devika Tryza Ayodahya ${ }^{2}, \mathrm{MD}$. Shariful Haque ${ }^{3}$

called the Book of Commercial Law (KUHD). The nature of commercial law which is an agreement that binds the parties to an agreement, is actually a part of civil law, specifically regarding the agreements regulated in Burgerlijk Wetboek (BW) that we are familiar with in the Civil Code Book (KUHPdt) Book III about the engagement.(Dirdjosisworo, 2006)

In business transactions, the most important legal basis in Indonesia is the Commercial Law Law (KUHD) and the Civil Code (KUHPdt), especially the provisions in Book III. The Commercial Law Act is a special part of the Civil Law in the agreement, or the term commercial law as "Lex Specialis" of civil law as "Lex Generalis".

Trade practices in the modern / globalization and transnational era, trade law in Indonesia which is based on the KUHD and KUHPdt (Book III) requires alignment of the reality of the needs of the world of trade, including by utilizing international trade law contained in bilateral and multilateral agreements, such as International Trade Law or World Trade Law, which includes international conventions and instruments on trade. (Adolf, I998)

Trade activities are one of the economic drivers in a country in order to produce national development. With trade, it guarantees that there is a general welfare that citizens can feel based on the rules that have passed.

At present, trade activities which include inter-country developments have developed quite rapidly. Ease of making transactions between countries without a barrier. At present negotiations relating to international trade are prevalent and play an important role in a country's economy. Likewise Indonesia, has followed the wheels of rotation in international trade activities. Indonesia has also been actively involved in several international trade negotiations and agreements, the results of which all contribute to the country's foreign exchange so that the results can support national development.

Forms of Indonesia's involvement in the world of international trade by becoming a member of the World Trade Organization. The World Trade Organization was signed in (Marrakesh, I994) which was officially established on I January 1995. The embryo of the birth of the WTO is the General Agreeement on Trade and Trade (GATT) which was established in 1947. After the convention of the establishment of the WTO in WTO Sign, GATT still stands as one part of the outcome of the WTO negotiations with the General Agreement on Trade and Service (GATS) and the Agreement on Trade Related Aspects of Intellectual Property Rights (TRIPs). The process of establishing the WTO was quite panning through lengthy negotiations in the Uruguay Round held at the GATT forum, from September 1986 to April 1994. The WTO Charter contains institutional 
rules and important attachments. Overall the final Uruguay agreement includes 28 agreements and 26,000 pages containing tariffs and services.(Adolf, 1998)

Joining Indonesia to become a member of the WTO by ratifying it through (Undang - Undang Nomor 7 Tahun 1994 Tentang Pengesahan Agreement on Establishing the World Trade Organization (WTO), n.d.) concerning Ratification of the Agreement Establishing the World Trade Organization. In addition, the Trade Facilitation Agreement is one of the agreements made at the WTO's 9th Ministerial Conference (KTM) in Bali in 2013. The Trade Facilitation Agreement is the first international agreement agreed upon by WTO members since the founding of the organization in 1995.

Trade Facilitation Agreement is an international agreement that aims to facilitate the movement and release of goods, including for goods that are in the transit period. The agreement also contains provisions regarding cooperation between customs authorities and technical authorities related to trade and compliance facilities. Besides this, the Trade Facilitation Agreement also opens opportunities for WTO members to get technical assistance in the field of trade facilitation from other WTO members who already have advanced trade facilitation procedures.("www.kemlu.go.id,” n.d.)

International Trade has four basic principles, namely the freedom of the parties to contract, the basic principles of Pacta Sunt Servanda (good faith), the basic principles of dispute resolution through arbitration, and the basic principles of freedom of communication.

Every country that has ratified the GATT-WTO agreement means that it agrees and agrees with existing rules, with the issuance of (Undang - Undang Nomor 7 Tahun 1994 Tentang Pengesahan Agreement on Establishing the World Trade Organization (WTO), n.d.) concerning Ratification of the Agreement on Establishing the World Trade Organization (WTO), the Final Act containing 38 agreements has been valid become part of national legislation. (Sood, 20II)

Indonesia's participation in the WTO and the implementation of various commitments included in it is inseparable from a series of policies in the international trade sector. Various agreements resulting from negotiations are agreements to improve the situation of international trade relations through efforts to expand access to goods and services markets, improve various trade regulations, broaden the scope of GATT provisions and discipline, and improve multilateral trade institutions or institutions, thus it is hoped that national economic integration will be more integrated with the world economy.(M.E.Retno Kadarukmi, 2013) 
The Effect of Halal Certificate towards Chicken Meat Import between Brazil and Indonesia according to Rule of GATT - WTO

Hamzah $^{1}$, Devika Tryza Ayodahya ${ }^{2}$, MD. Shariful Haque ${ }^{3}$

Indonesia has carried out export and import activities to various parts of the world. Indonesia exports various goods and products and Indonesia also receives goods and products from other countries. In carrying out export and import transactions, various conditions and restrictions on certain types of goods or certain export-import commissions are subject to, and special requirements including procedures for handling and safeguarding them. Each country has its own rules in export and import transactions, so it is very necessary to keep abreast of developments in regulations and trading systems in other countries as well as in Indonesia itself.

Indonesia itself has special rules regarding the import of goods, especially imports of foodstuffs. In the implementation of international trade activities in Indonesia, one of Indonesia's policies has caused disputes with other countries, namely the protection policy of the poultry sector by stopping the import of chicken meat from Brazil. The Brazilian party which stated that its market access had been closed into Indonesia for seven years since 2009. This caused Brazil to suffer a huge loss because it could not carry out the export of chicken meat to Indonesia.(Marrakesh, 1994)

\section{B. THEORITICAL}

(Undang - Undang Nomor 7 Tahun 1994 Tentang Pengesahan Agreement on Establishing the World Trade Organization (WTO), n.d.)concerning Ratification of the Agreement Establishing the World Trade Organization, it is explained that one of the discussions in the 1986 Round of I994 through 1994 was regarding Non-Tariff Measures aimed at to reduce or eliminate various nontariff barriers to trade, while taking into account commitments to reduce as many trade barriers as possible (Standstill and Rollback Principles).

Non-Tariff Barriers or Non-Tariff Measures are non-tariff policies imposed by the government in order to support and protect domestic producers who are able to inhibit the entry of foreign products into the domestic market. These obstacles are in the form of technical requirements that must be met by a product before entering the Indonesian market, including halal certification obligations for all foreign products that will enter Indonesia.

From the policy of importing chicken meat in Indonesia, Brazil demands that Indonesia conduct trade protection where it violates various WTO rules, including the Agreement on Sanitary and Phytosanitary Measures, the Agreement on Technical Barriers to Trade, the Agreement on Agriculture, The Agreement on Import Licensing Procedures, and Agreement on Shipping Inspection. This dispute has been processed in (WTO, n.d.), Indonesia - Measuring Concerning the 
Importation of Chicken Meat and Chicken Products.("Brasil Gugat ke WTO, Indonesia Tetap Pertahankan Syarat Halal," n.d.)

One of the points of the lawsuit is that (Undang - Undang Nomor 33 Tahun 2014 Tentang Jaminan Produk Halal, n.d.) Regarding Guaranteed Halal Products and the Association of the Minister of Agriculture of the Republic of Indonesia Number 139 / Permentan / PD.410 / I2/2014 Regarding Importation of Carcasses, Meats, and / or Processed Products into the Territory of the Republic of the Republic Indonesia. Brazil considers that the two laws and regulations are considered as a way to prohibit the import of chicken meat and chicken products, and that the requirements for slaughter and halal labeling are discriminatory.

Based on the description above, the writer is interested in discussing and explaining more about "The Effect of Halal Certificates on the Import of Chicken Meat Between Brazil and Indonesia Based on GATT - WTO Rules". The problems faced are how the impact of the halt in the import of chicken meat by Brazil because of the issue of halal labeling and how to resolve the dispute.

The purpose of this research is to analyze things including the implementation of law based on the ratification of the GATT - WTO by Indonesia regarding the dispute over the import of chicken meat by Brazil against Indonesia and how Indonesia's efforts in handling disputes submitted by Brazil that have arrived at the WTO organization.

\section{METHODOLOGY}

The results of this study will contribute to the development of legal science, particularly regarding the implementation of the law against disputes on the import of chicken meat by Brazil, the discussion of this problem is expected to be a guideline for the Indonesian state as a food importer to be able to take steps to provide security and comfort for the Indonesian people. the majority are Muslim in consuming imported food.

This study uses a normative juridical approach, the approach used in this study is a normative approach,(Muhammad, 2004) meaning that the existing problems are examined based on existing laws and regulations. This normative approach is summarized by adding other data as support. The approach implements existing legal provisions with legal events that occur in support of primary research.(Dirdjosisworo, 2006)

The method used in writing this article uses the method of normative legal research. In this case reviewing a legal problem from the point of international legal instruments in solving existing problems. The type of normative legal research used is the statute approach and the case approach in resolving the issue of imported 
The Effect of Halal Certificate towards Chicken Meat Import between Brazil and Indonesia according to Rule of GATT - WTO

Hamzah $^{1}$, Devika Tryza Ayodahya ${ }^{2}, \mathrm{MD}$. Shariful Haque ${ }^{3}$

chicken meat dispute between Brazil and Indonesia. The analysis technique in this article, namely the processing of collected legal materials obtained from library research and then analyzed using primary legal materials and secondary legal materials obtained, the completeness and clarity of which are examined for classification and systematic and consistent preparation so that they can be used as a reference in conducting analysis using description techniques, namely by describing the results of research with the aim of obtaining an overall picture but still systematic, especially regarding the facts relating to existing problems.

\section{RESULTS AND DISCUSSION}

\section{National Legal System Regarding Halal Certification in Indonesia}

The legal system in Indonesia as a system of rules that applies in the country of Indonesia is a system of rules that is so broad, consisting of legal elements, where the legal elements are interlocked with one another, mutually influence and complement each other. Therefore, discussing one field or element or subsystem of law in force in Indonesia cannot be separated from the others, so that it is similar to the human body, the legal element is like an organ whose existence cannot be separated from other organs.(Bisri, 2012)

One side of people's lives is regulated by Islamic Law Dogma is the enactment of (Undang - Undang Nomor 33 Tahun 2014 Tentang Jaminan Produk Halal, n.d.) concerning Halal Product Guarantee. The Act as a legal basis to provide legal protection for Muslim consumers against the uncertainty of the use of various halal food and beverage products both in the form of goods and services in accordance with Islamic legal obligations.(Aal Lukmanul Hakim, 2015)

Halal Certificate Guidelines issued by the Ministry of Religion explained that halal products are products that meet halal requirements in accordance with Islamic law, including(Departemen Agama RI, 2008):

I. Does not contain pork and ingredients derived from pigs;

2. Does not contain substances which are forbidden such as materials derived from human organs, blood, and impurities;

3. All material derived from animals slaughtered according to Islamic Shari'a procedures;

4. All storage, sales, processing, management and transportation sites may not be used for pigs and / or other non-halal goods. If it has been used for pigs and / or other non-halal goods, it must be cleaned in accordance with Islamic Sharia procedures;

5. All food and drinks that do not contain khamar. 
The position of halal certification in the Indonesian national legal system has a central position, because halal certification is included in (Undang - Undang Nomor 33 Tahun 2014 Tentang Jaminan Produk Halal, n.d.) concerning Halal Product Assurance which is a legal system part of the legal system, namely the legal substance that has legal force and legal certainty as well as imperative. And this is an effort to protect consumers in Islamic law.(Panji Adam, 2017)

The Indonesian Ulema Council (MUI) is an NGO that guides, fosters and nurtures Muslims throughout Indonesia, which has a goal: first, to assist the government in doing matters relating to Muslims, such as issuing fatwas regarding the halal status of a food product, second, determining the truth of a sect in Islam, third, regulating all matters relating to the relationship of an adherent of Islam with his environment.

As an institution that helps the government in implementing the Halal Product Guarantee System, it is better for halal certification in Indonesia as well as cooperation with overseas halal certification institutions should be carried out by MUI.

\section{Chicken meat import dispute between Brazil and Indonesia and its settlement}

Indonesia does not intend to prevent the importation of chicken meat or processed chicken products from any country including Brazil. Indonesia only wants to guarantee that imported chicken meat and processed chicken products are not only safe and healthy, but guaranteed halal, given the majority of Indonesian citizens are Muslim.

Indonesia's efforts to ensure health and safety and further halal conditions have resulted in the elimination of several steps to import chicken meat and was opposed by Brazil, following Indonesia's steps to stop the import of chicken meat outlined by Brazil, namely(WTO, n.d.):

I) General Prohibition on the Import of Chicken Meat and Chicken Products;

2) Prohibition of Importing Prepared or Preserved Chicken Meat and Chicken Meat (Positive List);

3) Limitation on Use of Imported Products;

4) Indonesian Tight Import Licensing Procedures;

5) Undue Delays in connection with the Sanitation Requirement Agreement;

6) Limitation on Transportation of Imported Products;

7) Discriminatory Application of Halal Labeling Requirements.

In this case, Brazil has consulted and filed a lawsuit against Indonesia through the Dispute Settlement Body (DSB) which is part of the WTO, the Dispute Settlement Body (DSB) as the WTO dispute resolution body in providing 
The Effect of Halal Certificate towards Chicken Meat Import between Brazil and Indonesia according to Rule of GATT - WTO

Hamzah $^{1}$, Devika Tryza Ayodahya ${ }^{2}, \mathrm{MD}$. Shariful Haque ${ }^{3}$

recommendations and formulating rules not allowed to add or reduce rights and obligations from the member countries listed in the agreement included in the list as agreements that can be submitted using the Article 3 DSU dispute resolution mechanism consisting of consultations, dispute resolution under Article XXIII (Panel), Panel process, WTO decision results, appeal through Appelatte Body, implementation decision, retaliation as the implementation of the decision.

The final decision for the dispute on chicken meat import, as released by the Ministry of Agriculture of the Republic of Indonesia, there are 3 (three) provisions won by Indonesia because Brazil is deemed to have failed to prove the provisions contradicting the WTO agreement, namely Discrimination on halal labeling requirements, direct transportation requirements, general prohibition on imports of chicken meat and chicken products.

Whereas 4 (four) provisions were won by Brazil because they were considered to be in conflict with the WTO Agreement, namely the list of products that could be imported (positive list), requirements for the use of imported products (itendeduse), import licensing procedures, delays in the approval process for veterinary health certificates (unduedelay).("Indonesia Tidak Akan Impor Daging Ayam Brasil," n.d.)

Upon the decision of Brazil's victory at the WTO, Indonesia and Brazil agreed not to appeal. The implication is that by not making an appeal, Indonesia must adjust or implement the WTO Panel's final decision which will be made with amendments and simplifications as in Minister of Agriculture Regulation No. 34 of 2016 concerning the Import of Carcasses, Meats, Offal, and / or Processed Products into the Territory of the Republic of Indonesia.("Kemtan Tegaskan Tidak Akan Mengimpor Daging Ayam dari Brasil,” n.d.)

Thus in the negotiations Brazil accepted Indonesia's offer not to import chicken meat to Indonesia because Indonesia was in a state of overproduction and took the opportunity to export beef to Indonesia and other cooperation that benefited both parties.

\section{E. CONCLUSION}

The position of halal certification in the National legal system in Indonesia has a central position, because halal certification is contained in (Undang - Undang Nomor 33 Tahun 2014 Tentang Jaminan Produk Halal, n.d.) concerning Halal Product Assurance which in the legal system is integrated in a single legal system, namely legal substance that has legal force and equal legal certainty that is imperative / binding. And this is an effort to protect consumers of consumers who are Muslim in the consumption of goods and or services. 
The cause of the chicken meat import dispute between Indonesia and Brazil is Indonesia's policy to stop importing Brazilian chickens since 2009 which caused Brazil to suffer losses. Brazil demands that Indonesia have carried out trade protection which violates various WTO rules, including the Agreement on Sanitary and Phytosanitary Measures, the Agreement on Technical Barriers to Trade, the Agreement on Agriculture, the Agreement on Import Licensing Procedures, and the Agreement on Pre-shipment

Inspection. ("www.kemlu.go.id," n.d.)

Settlement of Brazilian chicken meat import dispute is resolved through the WTO DSB mechanism with the rules of the DSU. In the final report decision on October 7, 2017 won by Brazil, 4 (four) provisions won by Brazil because they were considered contrary to the WTO Agreement, namely the list of products that can be imported (positive list), terms of use of imported products (itendeduse), import licensing procedures, postponement of approval process for veterinary health certificates (unduedelay). Indonesia and Brazil agree not to appeal and carry out an agreement that Brazil accepts Indonesia's offer not to import chicken meat to Indonesia because Indonesia is in a state of overproduction and takes the opportunity to export beef to Indonesia and other partnerships that benefit both parties.

\section{REFERENCES}

Aal Lukmanul Hakim. (2015). Dissecting the contents of law of Indonesia on Halal Product Assurance. Indonesia Law Review. Volume 5, Nomor I. Adolf, H. (I998). Hukum Ekonomi International Suatu Pengantar. Jakarta: PT Raja Grafindo Persada.

Bisri, I. (2012). Sistem Hukum Indonesia: Prinsip-Prinsip \& Implementasi Hukum di Indonesia. Jakarta: PT Raja Grafindo Persada.

Brasil Gugat ke WTO, Indonesia Tetap Pertahankan Syarat Halal. (n.d.). Retrieved from m.tribunnews.com/bisnis/2016/I0/I4/brasil-gugat-ke-wto-indonesiatetap-pertahankan-syarat-halal-dalam-importasi-daging-ayam

Departemen Agama RI. (2008). Panduan Sertifikasi Halal. Direktorat Jenderal

Bimbingan Masyarakat Islam Dan Penyelenggaraan Haji.

Dirdjosisworo, S. (2006). Pengantar Hukum Dagang Internasional. Bandung: PT Refika Aditama.

Indonesia Tidak Akan Impor Daging Ayam Brasil. (n.d.).

Kemtan Tegaskan Tidak Akan Mengimpor Daging Ayam dari Brasil. (n.d.).

Retrieved from https://m.kontan.co.id/news/kemtan- tegaskan-tidak-akan- 
The Effect of Halal Certificate towards Chicken Meat Import between Brazil and Indonesia according to Rule of GATT - WTO

Hamzah $^{1}$, Devika Tryza Ayodahya ${ }^{2}$, MD. Shariful Haque ${ }^{3}$

mengimpor-daging-ayam-dari-brasil

M.E.Retno Kadarukmi. (2013). Dampak Implementasi GATT/WTO Terhadap Ekspor Impor Indonesia. Jurnal Administrasi Bisnis, Volume 9, Nomor I.

Marrakesh. (1994). Indonesia Stop Impor Daging dari Brasil. Retrieved from https://bisnis.tempo.co/read/859I55/indonesia-stop-impor-daging-daribrasil

Muhammad, A. (2004). Hukum dan Penelitian Hukum. Bandung: PT Citra Aditya Bakti.

Panji Adam. (20I7). Kedudukan Sertifikasi Halal Dalam Sistem Hukum Nasional Sebagai Upaya Perlindungan Konsumen Dalam Hukum Islam. Amwaluna Jurnal, Volume I, Nomor I.

Sood, M. (20I I). Hukum Perdagangan International. Jakarta: PT Raja Grafindo Petsada.

Undang - Undang Nomor 33 Tahun 2014 Tentang Jaminan Produk Halal. (n.d.).

Undang - Undang Nomor 7 Tahun 1994 Tentang Pengesahan Agreement on Establishing the World Trade Organization (WTO). (n.d.).

WTO, D. (n.d.). "Report of The Panel DS:484 Indonesia-Measures Meat

Chicken and Chicken Products." Retrieved from

http://www.wto.org/english/tratop_e/dispu_e/484r_e.pdf

www.kemlu.go.id. (n.d.). Retrieved from www.kemlu.go.id 